\title{
SWAINSON'S HAWK PRODUCTIVITY AND FIVE-YOUNG NEST
}

\section{STUART HOUSTON, 863 University Drive, SK S7N 0J8}

This is an account of a long-term study, but is also a story about four elements of incredibly good fortune.

Imagine initiating a study of the Ferruginous Hawk, which led to an even larger study of the Swainson's Hawk. Imagine what an impetus Jean Harris has given my hawk-banding program, finding 729 Swainson's Hawk nests, thereby propelling me into top spot among Swainson's Hawk banders. Imagine following this hawk through 12 consecutive years of excellent productivity, three years of good productivity, ten years of poor productivity, and then having the satisfaction of productivity in 1997 suddenly jumping back to equal the "good old days." And, especially imagine the excitement, in 1997, when Jean found the world's first recorded nest with five healthy nestlings almost ready to fledge. It was one of the most exhilarating experiences in 55 years of banding.

I like to say that when things go well, it reflects good management and when things go badly, that is bad luck. But when it comes to Swainson's Hawk and Jean Harris, I am the first to admit to being just plain lucky.

I did not plan a long-term study, I stumbled into it. In 1969, concerned about the drastically retracting range of Ferruginous Hawk in Saskatchewan, I encouraged my sub-permittee, Doug Whitfield, to check out a few former Ferruginous Hawk locations, west of Kindersley, that Glen A. Fox had reported in 1960. Doug went to four nests and had unexpected success: two nests had five young and two others had four young each. Although Ray Salt at Rosebud, $A B$, had mapped the migration routes and wintering grounds of Alberta Ferruginous Hawks in the $1930{ }^{8},{ }^{8}$ nothing was known of the movement of Saskatchewan birds. Ferruginous Hawk banding has been an annual event ever since Doug's first success ${ }^{3}$.

The next bit of luck concerned the time and place of the weekend camp of the Kindersley Boy Scouts, the only year we crossed paths at banding time. On 17 June 1972, when checking Ferruginous nests on the Kindersley-EIna PFRA Pasture, we saw that the solitary tree in the ravine near Teo Lake had an active pair of hawks. The Boy Scouts tents were $300 \mathrm{~m}$ away. Here was an opportunity to enrich the scouts' experience, so I went over and asked whether the scouts wished to observe the banding operation. To my surprise the enthusiastic scout master turned out to be Keith Harris, who had grown up on a farm three miles south of my hometown of Yorkton. His first cousin had found a Great Horned Owl nest for me there in 1953. Better yet, Keith informed me that his wife, Jean, was interested in hawks and had a couple of Swainson's Hawk nests that I might wish to visit the following month. Thus, a chance encounter led to annual assistance from Jean in finding nests of both Buteo species; her Swainson's peaked at 62 nests in 1987 (Table 1).

\section{Swainson's Hawk productivity}

Apart from one unexplained drop in nests found in 1976, Jean covered a 


\begin{tabular}{|c|c|c|c|c|c|c|}
\hline Year & $\begin{array}{l}\text { Total } \\
\text { nests }\end{array}$ & $\begin{array}{l}\# \text { nests } \\
\text { success }\end{array}$ & $\begin{array}{c}\text { \# young } \\
\text { banded }\end{array}$ & $\begin{array}{r}\text { \# nests } \\
\text { failed }\end{array}$ & Ratio yg./successful nest & $\begin{array}{l}\% \text { Nests } \\
\text { Successf }\end{array}$ \\
\hline 1972 & 3 & 2 & 4 & 1 & 2.00 & $66.67 \%$ \\
\hline 1973 & 7 & 5 & 11 & 2 & 2.20 & $71.43 \%$ \\
\hline 1974 & 9 & 6 & 14 & 3 & 2.33 & $66.67 \%$ \\
\hline 1975 & 11 & 6 & 13 & 5 & 2.17 & $54.55 \%$ \\
\hline 1976 & 2 & 1 & 3 & 1 & 3.00 & $50.00 \%$ \\
\hline 1977 & $1 \overline{5}$ & 10 & 25 & 5 & 2.50 & $66.67 \%$ \\
\hline 1978 & 17 & 14 & 41 & 3 & 2.93 & $82.35 \%$ \\
\hline 1979 & 19 & 15 & 38 & 4 & 2.53 & $78.95 \%$ \\
\hline 1980 & 15 & 9 & 19 & 6 & 2.11 & $60.00 \%$ \\
\hline 1981 & 20 & 17 & 33 & 3 & 1.94 & $85.00 \%$ \\
\hline 1982 & 26 & 24 & 50 & 2 & 2.08 & $92.31 \%$ \\
\hline 1983 & 47 & 32 & 59 & 15 & 1.84 & $68.09 \%$ \\
\hline SUBTOT & 191 & 141 & 310 & 50 & 2.20 Excellent production & $73.82 \%$ \\
\hline 1984 & 35 & 20 & 36 & 15 & 1.80 & $57.14 \%$ \\
\hline 1985 & 38 & 32 & 67 & 6 & 2.09 & $84.21 \%$ \\
\hline 1986 & 41 & 38 & 81 & 3 & 2.13 & $92.68 \%$ \\
\hline SUBTOT & 114 & 90 & 184 & 24 & 2.04 Good production & $78.95 \%$ \\
\hline 1987 & 62 & 49 & 80 & 13 & 1.63 lowest ratio ever & $79.03 \%$ \\
\hline 1988 & 39 & 20 & 27 & 19 & 1.35 even lower & $51.28 \%$ \\
\hline 1989 & 48 & 28 & 42 & 20 & 1.50 still low & $58.33 \%$ \\
\hline 1990 & 47 & 34 & 50 & 13 & 1.47 still low & $72.34 \%$ \\
\hline 1991 & 41 & 24 & 28 & 17 & 1.17 very low & $58.54 \%$ \\
\hline 1992 & 47 & 29 & 40 & 18 & 1.38 still low & $61.70 \%$ \\
\hline 1993 & 23 & 9 & 11 & 14 & 1.22 very low & $39.13 \%$ \\
\hline 1994 & 26 & 25 & 47 & 1 & 1.88 best in 7 years & $96.15 \%$ \\
\hline 1995 & 35 & 30 & 42 & 5 & 1.40 low again & $85.71 \%$ \\
\hline 1996 & 28 & 16 & 27 & 12 & 1.69 better than Mantario & $57.14 \%$ \\
\hline SUBTOT & 396 & 264 & 394 & 132 & 1.49 poor production & $66.67 \%$ \\
\hline 1997 & 28 & 26 & 62 & 2 & 2.38 like old times & $92.86 \%$ \\
\hline TOTAL & 729 & 521 & 950 & 208 & 1.82 young/ successful nest & $71.47 \%$ \\
\hline
\end{tabular}

Table 1. Swainson's Hawk nests found by Jean Harris, Kindersley area, SK

wider area each year and found more and more nests. Like us, Jean is careful not to go near a Swainson's Hawk nest early in incubation. Only in midJune are nesting pairs watched and then only from a distance, for fear of nest desertion. As a result we have no statistics on early nest desertion. During the first 14 years, from 60 to $90 \%$ of Jean's known pairs were successful in a given year, and productivity was more than two young per successful nest. From 1984 to 1986 this figure fell to almost exactly two per nest.

The next ten years, 1987 to 1996 showed more nest failures and declining productivity to only 1.17 young per successful nest in 1991 and 1.22 in 1993. Mid-breeding nest failures rose to an all-time high of $61 \%$ in 1993 .

Another check on productivity is to graph the number of nests, province wide, with one, two, three and four young (Figure 1). From 1944 to 1994, only $19 \%$ of 3039 banded young were produced in nests with only one young ${ }^{4}$. The percentage of nests raising only one young to banding age, the solid black line on the graph, was $20 \%$ in the first 12 years, then rose to $50 \%$ or more 


\section{Swainson's Hawks, Saskatchewan}

\section{Percent of Nests with 1, 2, 3, or 4 young}

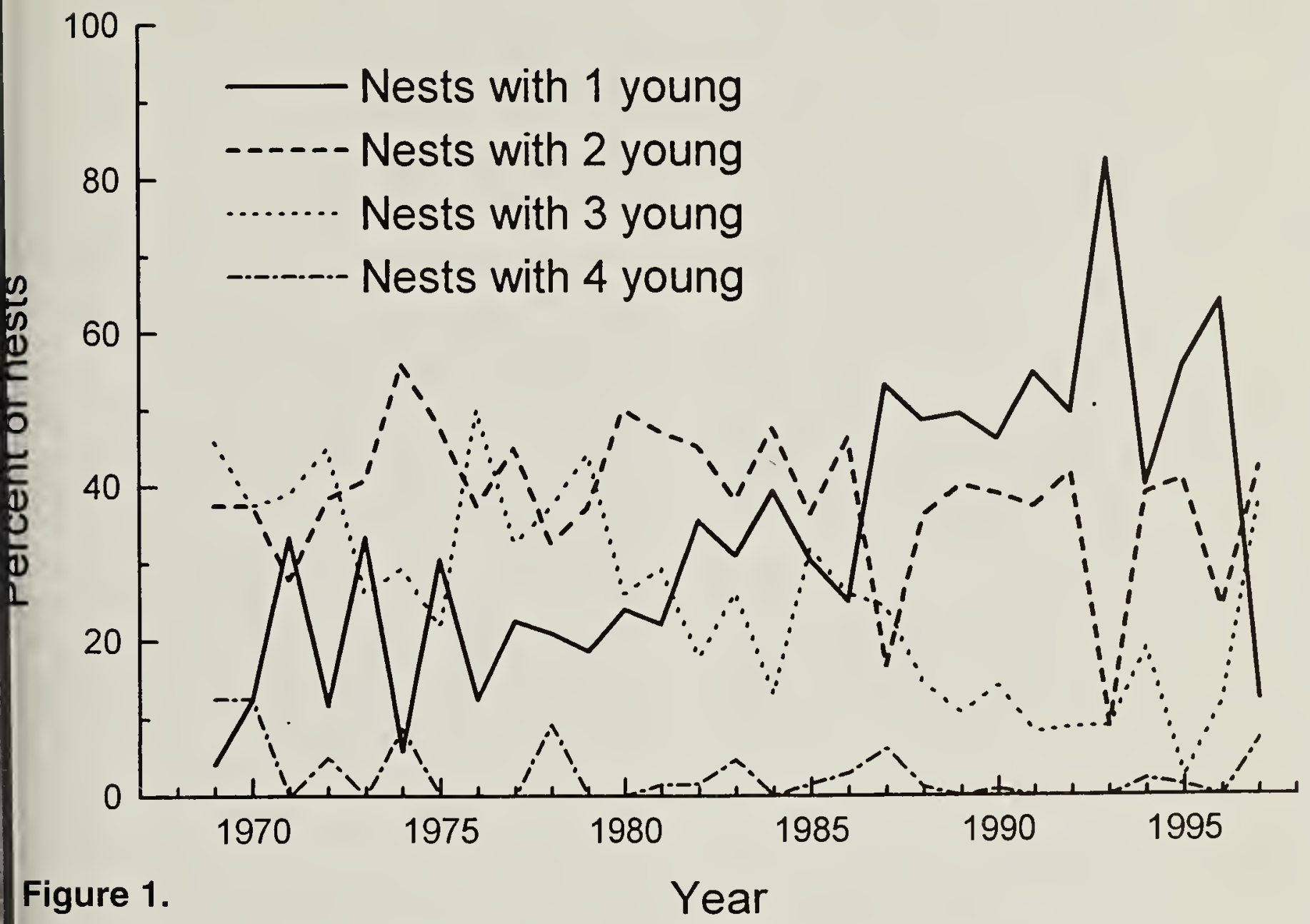

from 1987 to 1996; peaking at $82 \%$ in 1993. Yet in 1997 this figure dropped back suddenly to $10 \%$.

\section{Swainson's Hawk Populations}

Between 1987 and 1996, the number of nesting pairs dropped by approximately $50 \%$. A similar approximately $50 \%$ drop occurred at Hanna, Alberta between 1989 and 1996. An even more drastic drop occurred in southwestern Saskatchewan (Josef K. Schmutz, mss., and Wayne C. Harris, pers. comm.).

\section{Speculation}

Grassland fragmentation no doubt has contributed to productivity declines in the Ferruginous Hawk and Burrowng Owl, but the Swainson's Hawk is much less a grassland specialist. Changing farm practices and chemical usage may be contributing causes. Ian Newton's wonderful "Population Ecology of Raptors" perhaps offers the best explanation: "almost every aspect of the natural population ecology of a given raptor species can be explained in terms of food." 6 The ten -year drop in numbers of Swainson's young per successful nest was accompanied by a drastic decline in numbers of Richardson's Ground Squirrel (RGS), a widespread phenomenon throughout the grasslands of southern Alberta and Saskatchewan. Our best guess is that numbers of RGS at Kindersley dropped below 5\%, perhaps $2 \%$ of their former numbers; which were everywhere considered "superabundant" in the $1970 \mathrm{~s}^{7}$. A similar RGS crash was not evident in parkland areas of Saskatchewan. One possible, partial, explanation of the ground squirrel decline was the appearance of the Red Fox, both at Luseland to the north 
and Kyle to the southeast, in the mid 1960s, with subsequent dramatic increases $^{2,5}$.

RGS roadkills were common from 1950 to 1987 . In over $10,000 \mathrm{~km}$ of travel each year, between 1992 and 1995, inclusive we saw only one such roadkill, whereas up to 3 Red Fox roadkills were encountered in one day. From 1992 through to 1996, days without a single RGS sighting were commoner than days without a Red Fox sighting. RGS numbers appeared to bottom out in 1993. By 1996 and 1997 there were increasing numbers of small pockets of RGS, sparingly distributed. The largest groups in 1996 being 20 near Hillsburgh Pasture Headquarters south of Brock and another nine near Laporte, on 21 June. These increases seemed insufficient to explain the sudden improvement in productivity in 1997. However, voles, which proliferated everywhere in southern Saskatchewan in 1997, offer at least a partial explanation. Vole numbers rivalled the years 1960 and 1969; all three springs followed some of the wheat and other crops lying unharvested all winter under the early snow. Although not reflected in prey remains in nests by banding time, this abundant food supply may have helped both species of Buteo get off to a good start in 1997.

\section{Five-young nest}

A thorough literature search revealed a single report of a five-egg clutch in 1915 , classed as questionable, and no reports of five young ${ }^{1}$. Hence it was a surprise on 23 July when we followed Jean Harris's directions to a nest alongside Highway 21, south Kerrobert, to find five healthy young Swainson's Hawks. The nest was $4.3 \mathrm{~m}$ above ground in a Manitoba Maple, along the north edge of a farm shelterbelt, and, in spite of the large brood we found two Richardson's Ground Squirrel skins in the nest. One adult was erythristic (reddish plumage) and one light. All five young were similarly erythristic and nearly ready to fledge: indeed one flew five $m$ and was replaced in the nest. This appears to

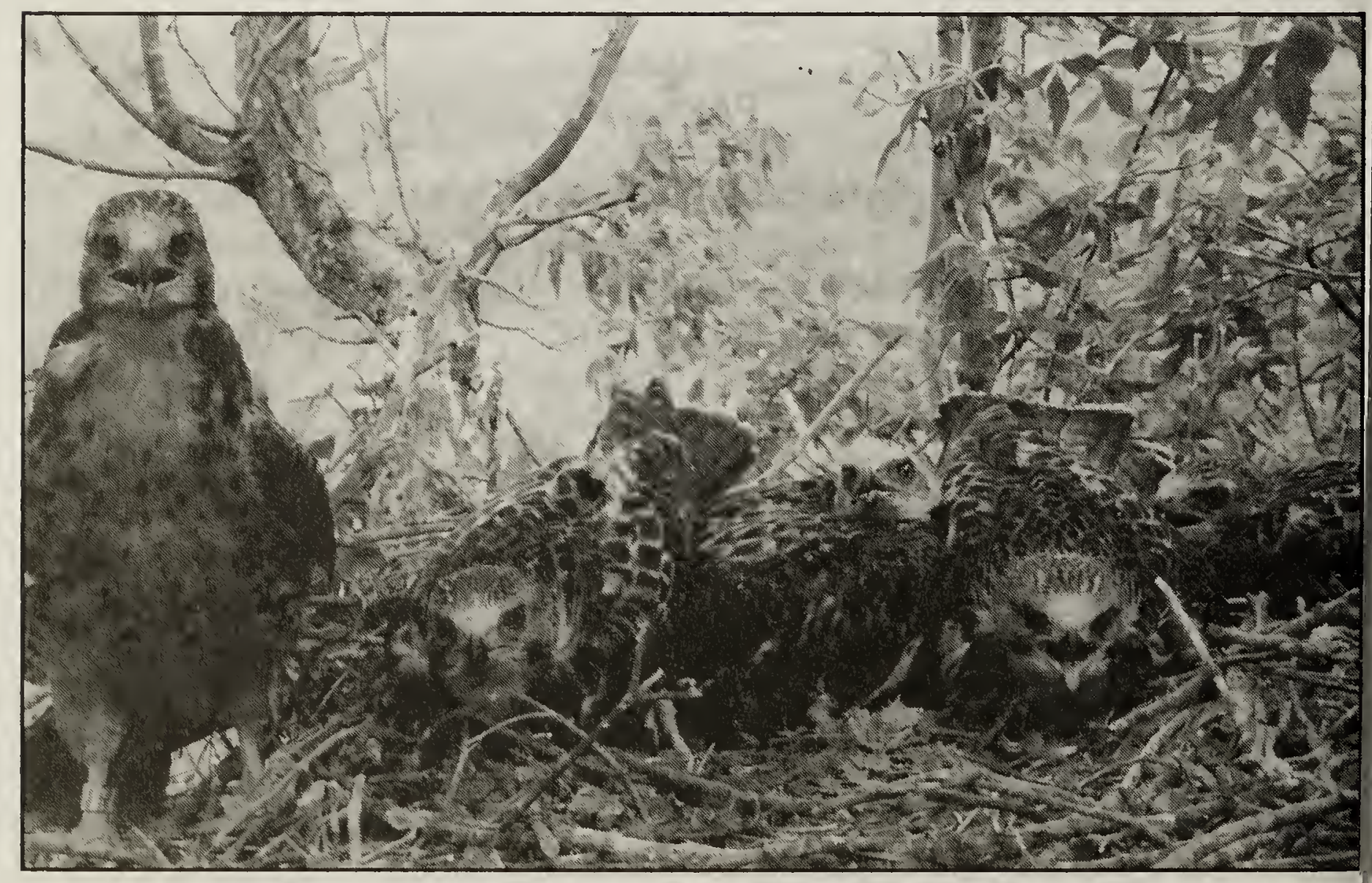

Five Swainson's Hawks in one nest.

Jean Harris 
be the world's first recorded Swainson's Hawk nest with five young.

1. ENGLAND, A.S., M.J. BECHARD, and C.S. HOUSTON. 1997. Swainson's Hawk (Buteo swainsoni). In The Birds of North America, No. 265 (A. Poole and F. Gillis, eds.). The Academy of Natural Sciences, Philadelphia, PA and the American Ornithologists Union, Washington, D.C.

2. FINLEY, K. 1996. The Red Fox invasion and other changes in wildlife populations in west-central Saskatchewan since the 1960s. Blue Jay 54:206210.

3. HOUSTON, C.S. 1995. Thirty-two consecutive years of reproductive success at a Ferruginous Hawk nest. J. Raptor Res. 29:282-283.
4. HOUSTON, C.S. and J.K. SCHMUTZ. 1995. Declining reproduction among Swainson's Hawks in prairie Canada. J. Raptor Res. 29:198-201.

5 JORDHEIM, S.J. 1995. Foxes in south-central Saskatchewan. Blue Jay 53:232-233.

6. NEWTON, I. 1979. Population ecology of raptors. Buteo Books, Vermillion, S.D.

7. ROTHFELS, M. and M.R. LEIN 1983. Territoriality in sympatric populations of Red-tailed and Swainson's Hawks. Can. Zool. J. 61:60-64.

8. SALT, R. 1939. Notes on recoveries of banded Ferruginous Rough-legged Hawks (Buteo regalis). Bird-Banding 10:80-84.

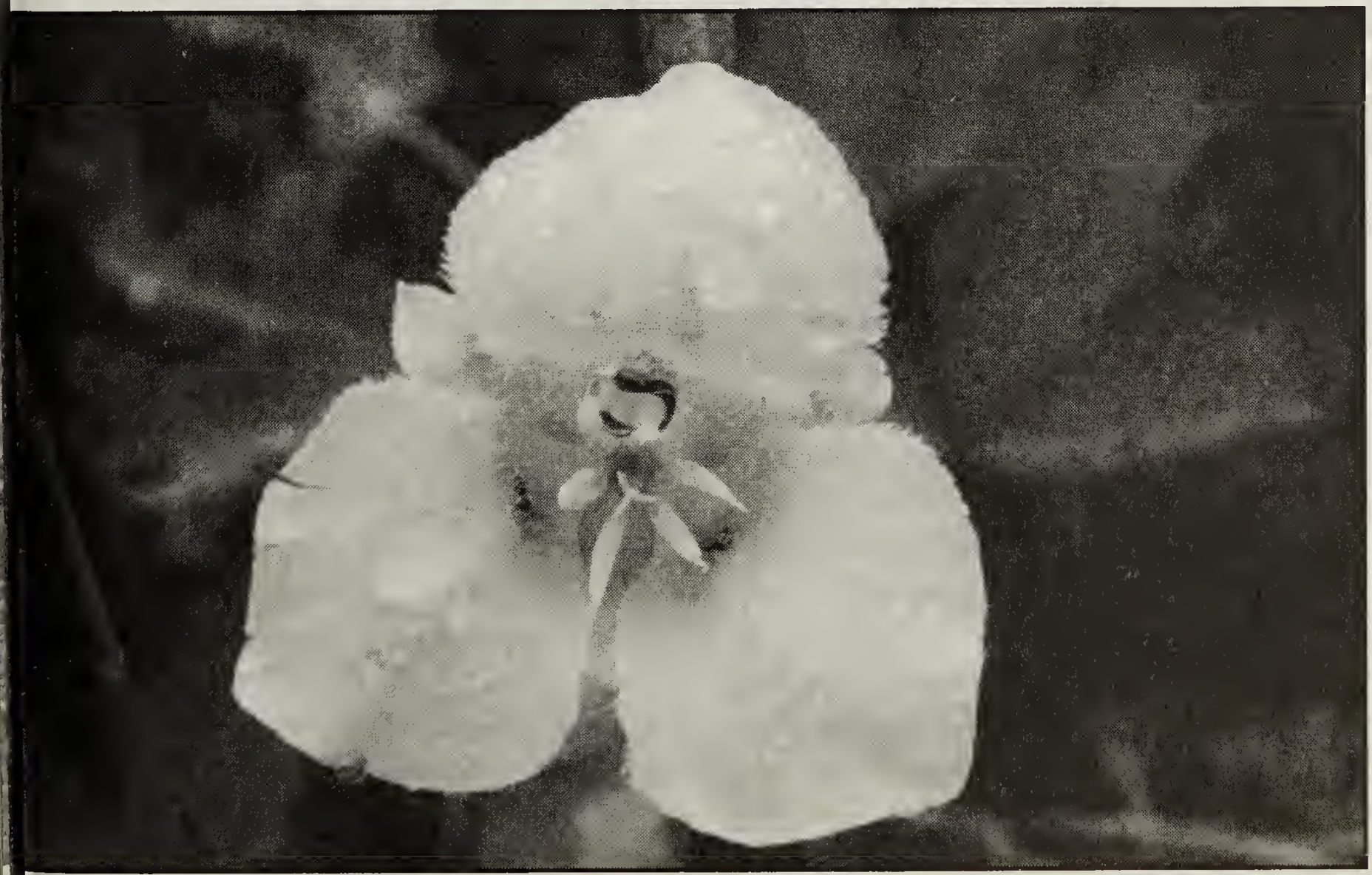

